\title{
The biotherapics Influenzinum and Oscilococcinum in the treatment of influenza virus flu.
}

\author{
Ana Luiza Marques de Oliveira1, Carla Holandino², \\ Camila Monteiro Siqueira ${ }^{2}$ \\ ${ }^{1}$ Instituto Hahnemanniano do Brasil (IHB), Rio de Janeiro, Brazil \\ 2 Universidade Federal do Rio de Janeiro, Brazil
}

\begin{abstract}
Introduction: The influenza virus flu is a widespread illness which is responsible for hundreds of thousands of deaths annually. About $20 \%$ of children and $5 \%$ of adults are infected with this virus every year. The disease is highly contagious and its transmission occurs by saliva particles of the infected person, expelled by breathing, talking and coughing [1]. Flu pandemics are generally caused by the appearance of a new subtype of the virus in humans, which occurs as a result of the existing flu in animal species transmitted to humans [2]. Despite the fact there are antiviral drugs, the virus develops mutations, creating resistance to these drugs in few days. Thus, the development of new therapies, including homeopathy, that can prevent and/or treat this disease becomes increasingly necessary. In this scenario, biotherapics appear as drugs that are made from biological products, such as secretions, tissues, organs whose compounding follows the homeopathic pharmacopeia. Objective: This study is a literature review on the treatment of flu with biotherapics used in clinical medicine, namely Influenzinum and Oscilococcinum. Method: Studies on the prescription of biotherapics for the prevention and cure of the flu as well as literature about the history and evolution of Homeopathy were reviewed in the present work. Influenzinum is a biotherapic made from the influenza vaccine from Pasteur Laboratory, while Oscillococcinum is obtained from the lysate of the liver and heart of the goose Anas barbaries. Results: Preliminary results showed that both medicines are widely used in clinical medicine. Influenzinum $9 \mathrm{CH}$ is prescribed for flu prevention and treatment, while Oscilococcinum is more used to reduce the severe symptoms in patients who already have the flu. Conclusion: Based on these results, it is possible to say that Influenzinum has a very important role in the prevention and cure of the influenza and Oscilococcinnum is useful in the relief of the symptoms caused by this disease.
\end{abstract}

Keywords: Influenza, Flu, Biotherapics, Homeopathy.

\section{References:}

[1] Eccles R. Understanding the symptoms of the common cold and influenza. Lancet Infect Dis. 2005; 5 (11): $718-725$.

[2] Shimizu K. History of influenza epidemics and discovery of influenza virus, Nippon Risho. 1997; 55(10):2505-2511.

\section{(c) BY-NC-ND Licensed to GIRI}

Support: authors declare that this study received no funding

Conflict of interest: authors declare there is no conflict of interest

Correspondence author: Ana Luiza Marques de Oliveira, analuamy@yahoo.com.br

How to cite this article: Oliveira ALM, Holandino C, Siqueira CM. The biotherapics Influenzinum and Oscilococcinum in the treatment of influenza virus flu: a literature review. Int J High Dilution Res [online] 2011 [cited YYYY Month dd]; 10(35): 94-94. Proceedings of the XXIV GIRI Symposium; 2010 Nov 05; Monte Carlo (Monaco). GIRI; 2010. Available from: http://www.feg.unesp.br/ ojs/index.php/ijhdr/article/view/443/477 